\title{
Radioimmunological Determination of Insulinlike
}

\section{Growth Factors I and II in Normal Subjects and}

\section{in Patients with Growth Disorders and Extrapancreatic}

\section{Tumor Hypoglycemia}

\author{
J. Zapf, H. Walter, and E. R. Froesch, Metabolic Unit, Department of \\ Medicine, University Hospital, CH-8091 Zürich, Switzerland
}

A B S TRACT Serum levels of immunoreactive insulinlike growth factors (IGF) I and II were determined by a modified IGF I and a new IGF II radioimmunoassay in normal children and adults, and in patients with acromegaly, isolated growth hormone deficiency, and extrapancreatic tumor hypoglycemia.

Serum samples were gel filtered by a simple routine procedure at acidic $\mathrm{pH}$ to dissociate and separate IGF from the IGF carrier protein.

Mean immunoreactive IGF I levels $( \pm S D$; corrected for crossreactivity of IGF II) were $193 \pm 58 \mathrm{ng} / \mathrm{ml}$ in normal adult subjects, $712 \pm 245 \mathrm{ng} / \mathrm{ml}$ in acromegalic patients and $24 \pm 14 \mathrm{ng} / \mathrm{ml}$ in patients with isolated growth hormone deficiency. The lack of growth hormone alone, irrespective of an otherwise normal hormonal status, appears to be responsible for the drastic decrease of IGF I levels.

Oversecretion of growth hormone does not increase the levels of immunoreactive IGF II: mean levels $( \pm S D$; corrected for crossreactivity of IGF I) in normal and acromegalic subjects are virtually identical $(647$ \pm 126 and $641 \pm 189 \mathrm{ng} / \mathrm{ml}$, respectively). Apparently, normal growth hormone levels stimulate IGF II production already maximally. However, in growth hormone deficiency immunoreactive IGF II is significantly decreased $(252 \pm 99 \mathrm{ng} / \mathrm{ml})$. Thus, IGF II, like IGF I, is growth hormone dependent. But in contrast to IGF I, the growth hormone dependence of IGF II seems to become apparent only at subnormal growth hormone levels.

In normal children IGF $I$ is age dependent: it is low in newborn cord sera $(51 \pm 20 \mathrm{ng} / \mathrm{ml})$ and gradually rises into the adult range with increasing age. At the onset of and during puberty mean IGF I levels lie above prepubertal values. In contrast, IGF II levels in normal children are independent of age and pubertal stage beyond the first year of life, whereas newborns have significantly lower IGF II values.

Hypoglycemia resulting from extrapancreatic tumors is not associated with increased immunoreactive IGF I or II levels. IGF I is decreased in most of the sera (mean level \pm SD:56 $\pm 39 \mathrm{ng} / \mathrm{ml}$ ) whereas IGF II lies in the normal range $(556 \pm 195 \mathrm{ng} / \mathrm{ml})$.

\section{INTRODUCTION}

The insulinlike growth factors (IGF) $\mathrm{I}$ and $\mathrm{II}^{1}$ are two polypeptides $(7,500 \mathrm{~mol} \mathrm{wt})$ that have been isolated from human serum. They have been identified as homologues of the insulin molecule $(1,2)$. However, they do not react with insulin antibodies (3). Their biological effects tested so far are qualitatively identical to those of insulin (4). They are also potent mitogens (4) and sulfation factors $(4,5)$.

The immunoreactive (IR) IGF I levels in man depend on the growth hormone status (6). IGF I can be classified as a somatomedin as originally defined by Daughaday et al. (7). In addition, IGF I appears to be structurally similar-if not identical-to somatomedin C (8-11).

Although some indirect evidence for the growth hormone dependence of IGF II has been obtained recently (6), conclusive evidence has been missing. It has now become possible to determine serum immunoreactive IGF II levels separately from those of IGF I and, thus, to get more direct information on its

\footnotetext{
Received for publication 18 March 1981 and in revised form 17 July 1981.

${ }^{1}$ Abbreviations used in this paper: HSA, human serum albumin; IGF, insulinlike growth factor; IR, immunoreactive; PBS, phosphate-buffered saline; RIA, radioimmunoassay; SM-A, somatomedin, A; SM-C, somatomedin C.
} 
regulation in different physiological and pathophysiological states. In this paper we describe a radioimmunoassay (RIA) for IGF-II and a modified IGF I RIA and their application in sera of normal subjects, patients with acromegaly and isolated growth hormone deficiency. In addition, we tried to answer the still pending question of whether or not extrapancreatic tumor hypoglycemia might be caused by elevated IGF levels. Despite the finding that total IGF as measured biologically and by competitive protein binding is not increased in these patients, and that IRIGF I was found decreased rather than increased (6), the possibility has not been excluded that this type of hypoglycemia may be associated with an elevation of IR-IGF II.

\section{METHODS}

Pure IGF I (prep. I/3) and IGF II (prep. 10SE IV), porcine insulin, insulin A and B-chain were kindly provided by Dr. R. E. Humbel, Zürich. The chemical and biological characteristics of the IGF preparations have been described in detail elsewhere $(1,2,4)$. Somatomedin A was generously supplied by Dr. L. Fryklund, Stockholm, somatomedin C by Dr. J. J. Van Wyk, Chapel Hill, NSILP by Dr. P. Poffenbarger, Galveston, Tex., porcine proinsulin and C-peptide by Dr. Geiger, Hoechst, West Germany, MSA (peak II, same as used in ref. 30) by Dr. Nissley and Dr. Rechler, National Institutes of Health, Bethesda, Md. mouse EGF by Dr. Orth, Nashville. Rabbit gamma globulin was obtained from Miles Laboratories, Inc., Elkhart, Ind., goat anti-rabbit gamma globulin serum and somatostatin from Calbiochem-Behring Corp., San Diego, Calif.

The iodination of IGF I and II was performed as described earlier (4). $1 \mu \mathrm{g}$ of IGF I or II was dissolved in $20 \mu \mathrm{l}$ of $0.005 \mathrm{~N}$ $\mathrm{HCl}$. Then $40 \mu \mathrm{l}$ of $0.25-\mathrm{M}$ phosphate buffer, $\mathrm{pH} 7.4$, and $10 \mu \mathrm{l}$ of $\mathrm{Na}{ }^{125} \mathrm{~J}(\mathrm{l} \mathrm{mCi}$, carrier-free, neutralized with $0.25 \mathrm{M}$ phosphate buffer, $\mathrm{pH}$ 7.4, immediately before use) were added and the reaction was started with $20 \mu \mathrm{l}$ of chloramine $\mathrm{T}(2 \mu \mathrm{g}$ in $0.04 \mathrm{M}$ phosphate buffer, $\mathrm{pH}$ 7.4). After $45 \mathrm{~s}$ the reaction was stopped with $30 \mu \mathrm{l}$ of sodiummetabisulfite ( $6 \mu \mathrm{g}$ in $0.04 \mathrm{M}$ phosphate buffer, $\mathrm{pH}$ 7.4). After addition of $250 \mu \mathrm{l}$ of $0.04 \mathrm{M}$ phosphate buffer containing $2 \mathrm{~g} / 100 \mathrm{ml}$ of serum albumin the reaction mixture was immediately applied to a Sephadex G-50 medium column $(2 \times 33 \mathrm{~cm})$, equilibrated with $0.1 \mathrm{M}$ ammonium acetate containing $200 \mathrm{mg} / 100 \mathrm{ml}$ of human serum albumin, and eluted with the same buffer (flow rate $27 \mathrm{ml} / \mathrm{h}$ ). The peak of radioactivity eluting between 50 and $70 \%$ bed volume was collected and stored at $-20^{\circ} \mathrm{C}$. $70-90 \%$ of the radioactivity of this peak was precipitable by $10 \%$ trichloroacetic acid (TCA), depending on the time of storage. $65-85 \%$ of the TCA-precipitable counts were immunoprecipitable with the corresponding antiserum. The specific radioactivity of the tracer ranged between 40 and $80 \mu \mathrm{Ci} / \mu \mathrm{g}$.

Production of antisera. Antibodies against IGF I and II were raised in six and four mature rabbits, respectively. $400 \mu \mathrm{g}$ of each of the pure polypeptides were dissolved in $270 \mu \mathrm{l}$ of $0.005 \mathrm{~N} \mathrm{HCl}$. Then $230 \mu \mathrm{l}$ of $1 \mathrm{M} \mathrm{NaHCO}$ were added followed by $500 \mu \mathrm{l}$ of $10 \%(\mathrm{wt} / \mathrm{vol}) \mathrm{KAl}\left(\mathrm{SO}_{4}\right)_{2} \cdot 12$ $\mathrm{H}_{2} \mathrm{O}$, upon which the mixture became turbid. It was then emulsified with $1 \mathrm{ml}$ of complete Freund's adjuvant. $0.5 \mathrm{ml}$ each of the emulsion was injected subcutaneously at four different sites of the scapular region. Booster injections of $10 \mu \mathrm{g}$ of the polypeptides in $0.5 \mathrm{ml}$ of incomplete Freund's adjuvant were administered subcutaneously at four different sites of the back of each animal within 2-wk intervals. 1 wk after each booster injection $15-20 \mathrm{ml}$ of blood was drawn from an ear vein and checked for the IGF antibody titer (see results). After clotting ( $1 \mathrm{~h}$ at room temperature, and $1 \mathrm{~h}$ at $4^{\circ} \mathrm{C}$ ) the blood was centrifuged and the serum was stored frozen at $-20^{\circ} \mathrm{C}$

Gel filtration of sera. All serum samples were gel filtered at acidic $\mathrm{pH}$ on Sephadex G-50 medium in order to dissociate and separate IGF from its carrier protein. $0.1 \mathrm{ml}$ of each serum sample is applied to small columns $(29 \times 0.8$ $\mathrm{cm})$ of Sephadex G-50 medium, equilibrated with $1 \mathrm{M}$ acetic acid. The upper end of each column is extended into a 10$\mathrm{ml}$ reservoir over the bed surface. The latter is covered by a tightly fitting porous nylon disc (1.5 $\mathrm{mm}$ high). The flow rate is regulated by two adjustable clamps. The upper one is adjusted so as to allow a flow rate of $\sim 10$ drops per minute, whereas the lower one serves to stop the flow when required. After applying the serum sample and letting it drain through the disc, the flow is stopped, the reservoir filled with a volume of $1 \mathrm{M}$ acetic acid equivalent to $50 \%$ of the bed volume and the flow again started. When the reservoir is empty the flow is shortly interrupted to refill the reservoir with a volume of $1 \mathrm{M}$ acetic acid corresponding to $30 \%$ of the bed volume. This second fraction (50-80\% bed volume) is collected in $15 \mathrm{ml}$ glass vials, lyophylized, washed with $2 \mathrm{ml} 0.1 \mathrm{M} \mathrm{NH}_{4} \mathrm{HCO}_{3}$ and relyophilized. The lyophilized fraction is then dissolved

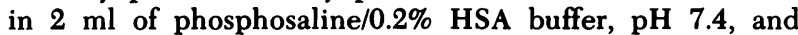
used at different dilutions in the RIA ("stripped" serum).

Recovery of added unlabeled and labeled IGF. When different amounts of unlabeled IGF I or II $(25,50$, and 100 $\mathrm{ng}$ ) were added to $0.1 \mathrm{ml}$ of phosphate-buffered saline/ $3 \%$ human serum albumin buffer ( $\mathrm{pH} 7.4)$, gel filtered, and processed as described above, the total recovery by RIA was $74.0 \pm 3.6 \%$ (mean $\pm \mathrm{SEM} ; n=6$ ). $63.0 \pm 3.2 \%$ was recovered in the $50-80 \%$, and $11.0 \pm 2.0 \%$ in the $0-50 \%$ bed vol fraction. The recovery in the $50-80 \%$ fraction of unlabeled IGF I or II $(25,50$, and $100 \mathrm{ng})$ added to $0.1 \mathrm{ml}$ of normal serum and chromatographed immediately was $66.0 \pm 2.7 \%(n=6)$. The percentage of total IGF I or II recovered in the $0-50 \%$ fraction (which contains the IGF carrier protein) corresponded to $10.1 \pm 1.1$ and $4.9 \pm 1.7 \%$, respectively, of the total amount added. The recovery between 0 and $80 \%$ bed vol after acidic gel filtration of IGF I or II tracer in $0.1 \mathrm{ml}$ serum samples was $71.7 \pm 1.0 \%(n=6)$ of the added counts. It was somewhat lower than the TCA precipitable $(81.5 \pm 1.4 \%)$ and identical to the immunoprecipitable radioactivity indicating that all of the intact IGF tracer was recovered between 0 and $80 \%$ bed vol. $11.3 \pm 1.4 \%$ of the radioactivity recovered in the $0-80 \%$ fraction $(8.2 \pm 1.1 \%$ of the total added counts) eluted in the $0-50 \%$ pool, and $88.7 \pm 1.3 \%(63.4 \pm 1.1 \%$ of the total added counts) in the $50-80 \%$ pool. When compared with the recovery by RIA of added unlabeled IGF (see above) a $25-30 \%$ loss of immunoreactive IGF in the 50-80\% fraction appears to result after gel filtration and lyophilization, which is as yet unexplained.

RIA of IGF I and II. The IGF I and II RIA are carried out at $4^{\circ} \mathrm{C}$ in PBS/0.2\% HSA buffer, pH 7.4. $0.1 \mathrm{ml}$ of the stripped serum sample is added to $0.2 \mathrm{ml}$ of $1: 1,000$ diluted IGF I or II antiserum (see above). After $24 \mathrm{~h}, 0.1 \mathrm{ml}$ of ${ }^{125}$ IIGF I or II $(\sim 20,000 \mathrm{cpm} ; \sim 0.2 \mathrm{ng})$ is added and the incubation carried on for another $24 \mathrm{~h}$. Then, $200 \mu \mathrm{l}$ of PBS/HSA buffer containing $40 \mu \mathrm{g}$ of rabbit gamma globulin and 50 $\mu l$ of goat anti-rabbit gamma globulin serum (diluted 1:2.5 with PBS buffer) is added. After $60 \mathrm{~min}$ at $4^{\circ} \mathrm{C}$ the tubes are centrifuged $(20 \mathrm{~min}, 3,500 \mathrm{~g})$, the supernate poured off, residual droplets sucked off with a pasteur pipette and the precipitate counted in a gamma counter (Tricarb, Packard 
Instrument Co., Inc., Downers Grove, Ill.). All stripped serum samples are tested in duplicate at two different dilutions (undiluted and diluted 1:2 in the IGF I RIA, and diluted 1:2 and 1:4 in the IGF II RIA). IGF I or II is determined from an IGF I or II standard curve (0.125-50 ng/assay tube). In addition, four different dilutions of a stripped control serum (prepared from a serum pool of normal donors) are run with each assay.

Patients. Most of the blood samples were obtained between 8 and 10 a.m. 11 normal female and 21 male donors were between 22 and 54 yr of age.

All acromegalic patients ( 22 females, 20 males, aged 27 to $65 \mathrm{yr}$ ) had elevated basal immunoreactive growth hormone levels $(10->100 \mathrm{ng} / \mathrm{ml})$ that were not suppressed below 6 $\mathrm{ng} / \mathrm{ml}$ by an oral load of $100 \mathrm{~g}$ of glucose. 20 of these patients had already been included in an earlier study on immunoreactive IGF I levels, where a slightly different methodology both with regard to gel filtration and IGF I determination had been used (6).

Sera from patients with isolated growth hormone deficiency (six males, six females; ages between 16 and $68 \mathrm{yr}$ ) were obtained from Dr. T. Merimee, Gainesville, Fla. The absence of growth hormone in these patients has been documented earlier $(12,13)$.

The group of children was included in this study as a second reference group in addition to that of normal adults. No attempt has been made to correlate IGF I or II with bone age, growth rate, testosterone or estrogen levels, etc. All children (age from $1 \mathrm{mo}$ to $16 \mathrm{yr}$ ) were free from clinical evidence of serious illness and had attended the pediatric outpatient clinic in Zürich (Professor A. Prader) and Petah Tiqva, Israel (Professor Z. Laron) for a followup of minor illnesses such as urinary or respiratory tract infections or allergic symptoms. Pubertal staging was performed according to Tanner (14).

Of the 22 patients with extrapancreatic tumor hypoglycemia (age between 13 and 85 yr; 8 females, 14 males), 8 had a fibrosarcoma, 2 a leiomyosarcoma, 3 a primary liver cell carcinoma, 1 a congenital mesoblastic nephroma, 1 a carcinoma of the stomach, 1 an undifferentiated carcinoma of the lungs, 1 a hemangioendothelioma, 1 a mesothelioma, 1 a carcinoma of the rectum (with liver metastases), 1 a benign fibroma of the lungs, 1 a fibroma of the pleura and 1 chronic myeloic leukemia. 10 of the patients had been included in an earlier study on IR-IGF levels (6). Blood sugar values, at the time of blood sampling ranged between 20 and $45 \mathrm{mg} / 100 \mathrm{ml}$. IR insulin levels at this time were below $10 \mu \mathrm{U} / \mathrm{ml}$.

\section{RESULTS}

Characteristics of the antiserum to IGF I and II. Antibodies against IGF I and II were detected after the second booster injection, i.e. around $5 \mathrm{wk}$ after the first injection of each of the polypeptides. Two of the rabbits immunized with IGF II died during that time for unknown reasons. After the three following booster injections a further rise of the antibody titer was observed. Henceforth, the antibody titer remained constant. Antibody production in different animals varied greatly. The best two antisera against IGF I and II (I/118-101077, and II/12-8678) bound $50 \%$ of the TCA-precipitable counts (35-45\% of totally added counts, depending on the time of storage of the tracers) at a final dilution of $1: 1,500$ and 1:2,000, respectively. Both antisera were used at a final dilution of $1: 2,000$ for the RIA. At this dilution specific binding (total binding minus binding in the presence of $50 \mathrm{ng} /$ assay tube of the unlabeled polypeptide) of the IGF I and II antisera was 34 and $40 \%$, respectively, of the added TCAprecipitable tracer (24-30 and $28-36 \%$ of the totally added counts, depending on the time of storage of the tracers).

Nonspecific binding in the presence of $50 \mathrm{ng}$ per assay tube of unlabeled IGF I or II was 9.5 and $11 \%$, respectively. These values are not significantly different from the binding of tracer in the absence of antiserum. The interassay variation for the IGF I and II RIA is \pm 10.2 and $\pm 10.9 \%$, respectively $(n=20)$. Including the chromatographic step, the interassay variation is \pm 14.8 and $\pm 11.2 \%$, respectively $(n=20)$. The intraassay variation is \pm 2.35 and $\pm 2.5 \%(n=30)$. $1 \mathrm{ml}$ of the IGF I antiserum bound $2.35 \mu \mathrm{g}$ of IGF I $(0.30 \mathrm{nmol}), 1 \mathrm{ml}$ of the IGF II antiserum $2.75 \mu \mathrm{g}$ of IGF II $(0.35 \mathrm{nmol})$. By using the above incubation procedure the sensitivity of both assays to pure IGF and stripped serum was increased twofold as compared with conditions where sample and tracer were added at the same time together with the antiserum.

Crossreactivities of IGF I, IGF II, SM-A, and SM-C in the IGF I and II RIA. As shown in Fig. 1, halfmaximal displacement of ${ }^{125}$ I-IGF $I$ is caused by $0.6-$ $0.7 \mathrm{ng} / 0.4 \mathrm{ml}$ of unlabeled IGF I $(0.2-0.23 \mathrm{nM})$, halfmaximal displacement of ${ }^{125}$ I-IGF II by $1-1.1 \mathrm{ng} /$ $0.4 \mathrm{ml}$ of unlabeled IGF II $(0.33-0.37 \mathrm{nM})$. Concentrations of IGF I and II as low as 0.10 and $0.25 \mathrm{ng} /$ tube are measurable in the respective RIA.

Scatchard plots constructed from the competition curves of Fig. 1 are curvilinear (after subtraction of nonspecific binding in the presence of $50 \mathrm{ng}$ of unlabeled hormone per tube). Thus, neither the IGF I nor the IGF II antiserum appears to contain a homogeneous population of antibodies.

Fig. 1 shows also the crossreactivities of IGF I, IGF II, somatomedin A and somatomedin C in the two RIA. The crossreactivity of IGF II in the IGF I RIA is $\sim 1 \%$, that of somatomedin $\mathrm{A} \sim 10 \%$, whereas somatomedin $\mathrm{C}$ behaves more or less identically to IGF I. In the IGF II RIA, IGF I, somatomedin $A$ and somatomedin $\mathrm{C}$ all show a crossreactivity of $\sim 10 \%$. With different dilutions of stripped serum the displacement curves are parallel to the standard curves in both RIA.

The following polypeptides did not crossreact in the IGF I RIA: somatomedin B and glucagon (up to 2.5 $\mu \mathrm{g} / \mathrm{ml}$ ), MSA-II, somatostatin, proinsulin, EGF and NSILP (up to $25 \mu \mathrm{g} / \mathrm{ml}$ ), ACTH A $_{-24}$, insulin, proinsulinC-peptide, isolated insulin A- and B-chain, prolactin and HGH (up to $250 \mu \mathrm{g} / \mathrm{ml}$ ). In the IGF II RIA no crossreactivity was observed with the following polypeptides: somatomedin B (up to $2.5 \mu \mathrm{g} / \mathrm{ml}$ ), MSA-II, EGF, HGH, ACTH ${ }_{1-24}$ and insulin B-chain (up to 25 


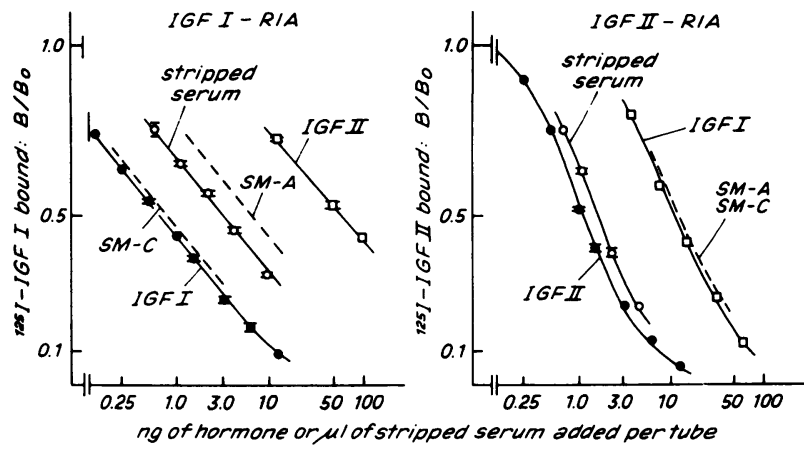

FIGURE 1 Competitive inhibition of the binding of ${ }^{125} \mathrm{I}$ labeled IGF I and IGF II to IGF I and II antiserum by unlabeled IGF I, IGF II, SM-A, SM-C, and stripped normal serum. Incubations were carried out at $4^{\circ} \mathrm{C}$ as described in Methods. The final dilution of the IGF I and II antiserum was $1: 2,000$. Stripped serum was obtained by acidic gel filtration on Sephadex G-50 (medium) as described in the text. Binding of labeled IGF I and II was expressed as the ratio between binding at different concentrations of added hormone or stripped serum (B) and binding in the presence of tracer alone $\left(B_{0}\right)$ after subtraction of nonspecific binding (in the presence of $50 \mathrm{ng}$ of IGF I or II per assay tube) from all values. All points give the mean of duplicates and bars the upper and lower range where it exceeds the size of the symbol.

$\mu \mathrm{g} / \mathrm{ml}$ ), proinsulin, insulin and insulin-C-peptide (up to $250 \mu \mathrm{g} / \mathrm{ml}$ ). Nonsuppressible insulinlike protein showed a crossreactivity of $0.01 \%$, insulin-A-chain of $0.0002 \%$.

IGF RIA in whole serum and in the presence of IGF carrier protein. When whole instead of stripped serum is used in the RIA, the IGF I values are between 50 to $70 \%$ lower than those determined in stripped serum. They depend on the serum dilution (Table I), since the displacement curves with whole serum are not parallel to the standard curve (Fig. 2). Surprisingly, the IGF II values determined in whole serum are in a similar range as those in stripped serum (Table I), but again, the dilution curves are not parallel to the standard curve (Fig. 2).

The interference with the IGF I and II RIA of IGF carrier protein in $0-50 \%$ bed vol fractions obtained after acidic gel filtration of several serum samples or in acid-lyophilized whole sera is demonstrated in Table II.

In six normal sera the IGF I and II RIA results obtained in the $50-80 \%$ bed vol fractions were $1.14 \pm 0.04$ and $1.79 \pm 0.08$-fold higher in the absence than in the presence of the $0-50 \%$ bed vol fraction. This ratio is different for sera from acromegalic patients: $0.82 \pm 0.02$ for IGF I and 1.16 \pm 0.06 for IGF II. For two sera from patients with extrapancreatic tumor hypoglycemia the factors were 1.5 for IGF I and 1.02 for IGF II. These relations are similar when the $50-80 \%$ bed vol fractions are compared with acid-lyophilized whole sera (Table II). Acid-ethanol extraction of the same serum samples
TABLE I

Comparison between the IGF I and II RIA Results Obtained at Two Different Dilutions of Whole and Stripped Serum from a Pool of Normal Adults, Acromegalic Patients, and Patients with Isolated Growth Hormone Deficiency

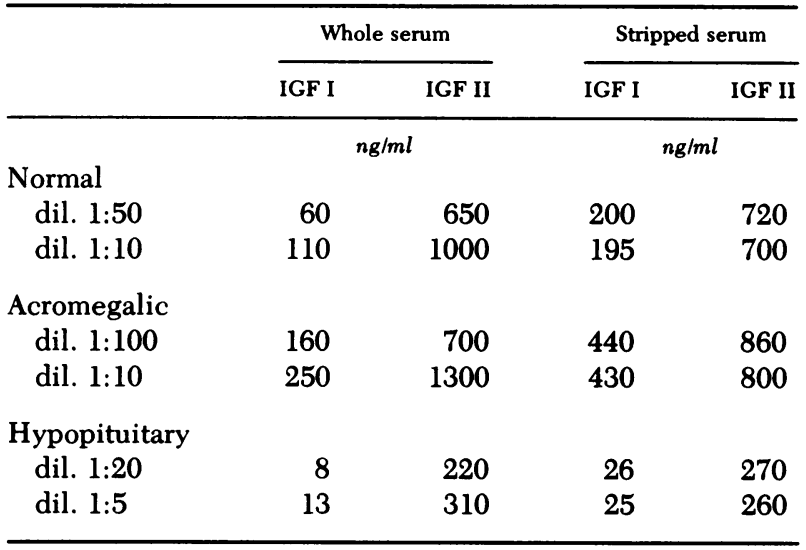

See also Fig. 2. Incubation conditions are given in Methods. The values are the means of duplicates (intraassay variation \pm 2.35 and $\pm 2.5 \%$ for IGF I and II, respectively).

according to the method of Daughaday et al. (15) yields both higher IGF I and II values than those obtained in $50-80 \%$ bed vol fractions; however, the ratio between the values obtained by these two methods remains relatively constant both for IGF I and II as well as for the three groups of patients' sera tested (0.700.71 for IGF I of the three groups, and 0.79-0.84 for IGF II of the three groups).

IGF values in gel filtered sera. Fig. 3 shows the IGF

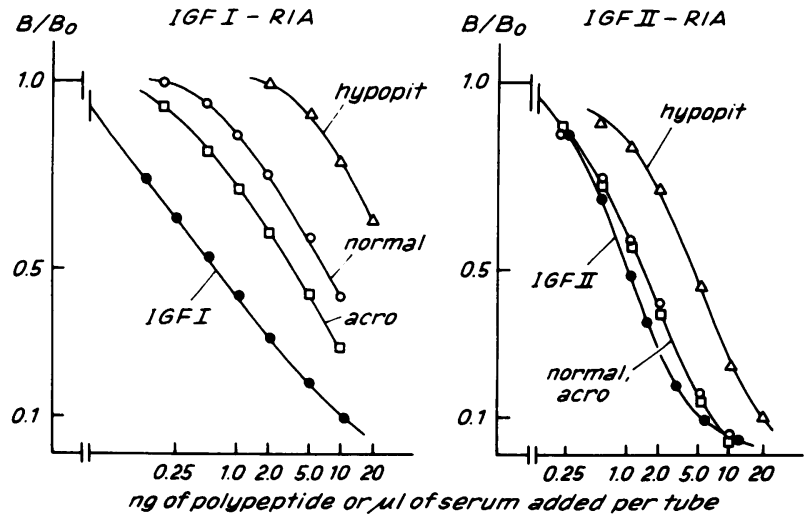

FIGURE 2 IGF I and II RIA carried out in whole serum of normal subjects, acromegalic, and hypopituitary patients. Incubations were carried out at $4^{\circ} \mathrm{C}$ as described in Methods. Antisera were used at a final dilution of $1: 2,000$. All points represent the means of duplicates (intraassay variation \pm 2.35 and $\pm 2.5 \%$ for the IGF I and II RIA, respectively). As in Fig. 1, binding is expressed by the ratio of $B / B_{0}$ after subtraction of nonspecific binding from all values. 
TABLE II

Effect of Different Methods of Pretreatment of Different Sera on the Results of the IGF I and II RIA

\begin{tabular}{|c|c|c|c|c|c|c|c|c|c|c|c|c|}
\hline & \multicolumn{4}{|c|}{$50-80 \%$ bed vol. fraction $*$} & \multicolumn{2}{|c|}{$\begin{array}{l}0-50 \%+50- \\
80 \% \text { bed vol } \\
\text { fract. }\end{array}$} & \multicolumn{2}{|c|}{$\begin{array}{l}\text { Lyophilized } \\
\text { with } \\
\text { acetic acid } \$\end{array}$} & \multicolumn{4}{|c|}{ Extracted with acid/ethanol" } \\
\hline & I & $\mathbf{A} / \mathbf{B}$ & II & $\mathbf{A} / \mathbf{B}$ & $\mathbf{I}$ & II & $\mathbf{I}$ & II & I & $\mathbf{A} / \mathbf{D}$ & II & $\mathbf{A} \mathbf{D}$ \\
\hline & \multicolumn{4}{|c|}{$n g / m l$} & \multicolumn{2}{|c|}{$n g / m l$} & \multicolumn{2}{|c|}{$n g / m l$} & \multicolumn{4}{|c|}{$n g / m l$} \\
\hline Normal & & & & & & & & & & & & \\
\hline 1 & 244 & 1.26 & 757 & 1.70 & 194 & 446 & 180 & 486 & 330 & 0.74 & 950 & 0.80 \\
\hline 2 & 326 & 1.07 & 660 & 1.60 & 306 & 412 & 251 & 496 & 430 & 0.76 & 740 & 0.89 \\
\hline 3 & 250 & 1.15 & 646 & 1.79 & 218 & 361 & 159 & 408 & 395 & 0.63 & 970 & 0.67 \\
\hline 4 & 167 & 1.23 & 538 & 1.62 & 136 & 332 & - & - & - & - & - & - \\
\hline 5 & 121 & 1.12 & 520 & 2.08 & 108 & 250 & - & - & - & - & 一 & - \\
\hline 6 & 170 & 1.02 & 516 & 1.92 & 166 & 269 & - & - & - & - & - & - \\
\hline \multicolumn{13}{|c|}{ Acromegaly } \\
\hline 7 & 750 & 0.84 & 543 & 1.33 & 890 & 406 & 730 & 480 & 1020 & 0.74 & 655 & 0.83 \\
\hline 8 & 530 & 0.87 & 512 & 1.16 & 610 & 442 & 555 & 476 & 720 & 0.74 & 625 & 0.82 \\
\hline 9 & 553 & 0.78 & 580 & 1.12 & 710 & 516 & 445 & 540 & 770 & 0.72 & 715 & 0.81 \\
\hline 10 & 670 & 0.80 & 375 & 1.04 & 840 & 360 & 680 & 340 & 1060 & 0.63 & 518 & 0.72 \\
\hline \multicolumn{13}{|c|}{ Tumorhypoglycemia } \\
\hline 11 & 40 & 1.67 & 361 & 0.93 & 24 & 388 & - & - & 62 & 0.65 & 494 & 0.73 \\
\hline 12 & 14 & 1.40 & 360 & 1.11 & 10 & 324 & 8 & 296 & 18 & 0.78 & 398 & 0.90 \\
\hline 13 & 56 & - & 418 & - & - & - & - & - & 84 & 0.67 & 460 & 0.90 \\
\hline
\end{tabular}

Sera from six normal adults, four acromegalic patients, and three patients with extrapancreatic tumor hypoglycemia were pretreated by four different methods before IGF I or II was determined in the RIA under the conditions described in Methods. * Sera $(0.1 \mathrm{ml})$ were gel filtered at acidic $\mathrm{pH}(1 \mathrm{M}$ acetic acid) on Sephadex G-50 columns $(29 \times 0.8 \mathrm{~cm})$. The $50-80 \%$ bed vol fractions were collected, lyophilized, washed wth $0.1 \mathrm{M} \mathrm{NH}_{4} \mathrm{HCO}_{3}$, and relyophilized. They were dissolved in $2 \mathrm{ml}$ of PBS/0.2\% HSA buffer, pH 7.4 and assayed at two different dilutions (Methods).

† Sera were gel filtered as described in A. 0-50 and 50-80\% bed vol fractions were combined, lyophilized, washed in $0.1 \mathrm{M}$ $\mathrm{NH}_{4} \mathrm{HCO}_{3}$, relyophilized, dissolved in $2 \mathrm{ml}$ of PBS/HSA buffer, and the insoluble denatured protein was centrifuged off before the samples were assayed in the IGF I and II RIA.

$\$ 0.1-\mathrm{ml}$ serum samples were acidified with $0.1 \mathrm{ml}$ of $2 \mathrm{M}$ acetic acid, incubated at room temperature for $2 \mathrm{~h}$ and then lyophilized. They were washed in $0.1 \mathrm{M} \mathrm{NH}_{4} \mathrm{HCO}_{3}$, relyophilized, dissolved in $2 \mathrm{ml}$ of PBS/HSA buffer and centrifuged before assay.

" $0.2-\mathrm{ml}$ serum samples were treated with acid/ethanol as described by Daughaday et al. (15). After centrifugation, $0.5 \mathrm{ml}$ of the supernate was neutralized with $0.15 \mathrm{ml} 1 \mathrm{M} \mathrm{NH}_{4} \mathrm{HCO}_{3}$, the alcohol was evaporated under a stream of air and the samples were then lyophilized, dissolved in $2 \mathrm{ml}$ of PBS/HSA buffer and centrifuged before they were assayed at two different dilutions.

All values are the means of duplicate incubations (intraassay variation \pm 2.35 and $2.5 \%$ in the IGF I and II RIA, respectively). $A / B$ and $A / D$ represent the ratios between the results obtained by method $A$ and $B$ or method $A$ and $D$, respectively.

I and II levels obtained in normal, acromegalic, and growth-hormone deficient patients. After correction for crossreacting IGF II in the IGF I-RIA ( 1\%; Fig. 1), the mean IGF I level in normal subjects is $193 \pm 58$ (SD) $\mathrm{ng} / \mathrm{ml}$; in acromegalic patients it is $712 \pm 245 \mathrm{ng} /$ $\mathrm{ml}$ and in growth-hormone deficient patients it is $24 \pm 14 \mathrm{ng} / \mathrm{ml}$. After correction for crossreacting IGF I in the IGF II-RIA ( $\sim 10 \%$, Fig. 1), mean IGF II levels are $647 \pm 126$ (SD) $\mathrm{ng} / \mathrm{ml}$ in normal adult subjects, $641 \pm 189 \mathrm{ng} / \mathrm{ml}$ in acromegalic patients, and $252 \pm 99$ $\mathrm{ng} / \mathrm{ml}$ in patients with isolated growth hormone deficiency. Thus, IGF II levels are not significantly different in normal and acromegalic patients $(P>0.1)$, whereas they are significantly below normal in the dwarf group $(P<0.01)$.

IGF I levels in children are age-dependent (Fig. 4). They lie significantly below the adult level in newborn cord sera and in children below $6 \mathrm{yr}$ of age. After $1 \mathrm{yr}$ of age there is a gradual rise of the mean IGF I level. With the onset of puberty IGF I rises above the normal adult level. The increase seems to occur earlier in girls than in boys. At that time most of the IGF I levels reach values close to or even within the range observed in adult acromegalic patients. This pattern is completely different for IGF II (Fig. 5): only in newborn cord sera and during the first year of life 

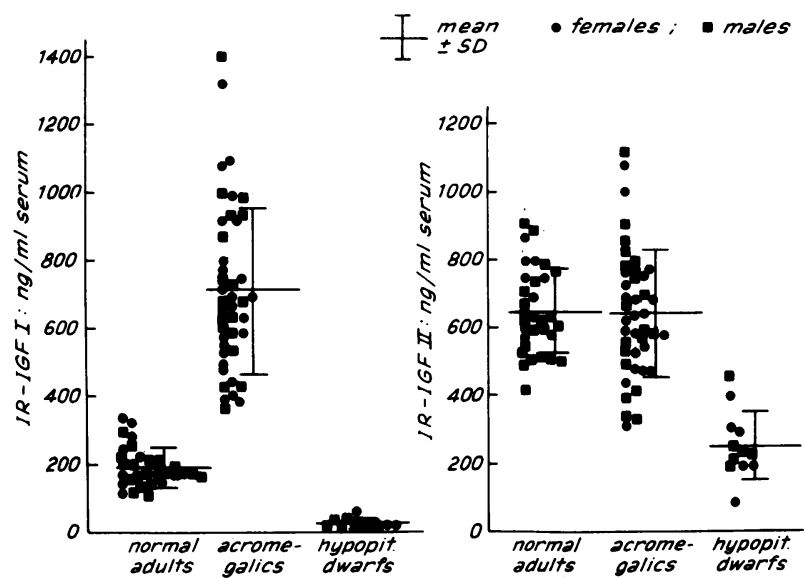

FIGURE 3 Serum immunoreactive IGF I and III levels in normal adults, acromegalic patients and patients with isolated growth hormone deficiency. IGF determinations were carried out in gel filtered sera (Methods). Bars represent the mean levels \pm SD. All individual values were corrected for crossreactivity of IGF I or III. $\bullet$, females; $\boldsymbol{a}$, males.

do IGF II levels lie below normal adult values ( $P$ $<0.01)$. After that time IGF II is no longer significantly different from normal in either of the age groups. Furthermore, IGF II appears independent of the pubertal stage.

IR-IGF I and II levels in patients with extrapancreatic tumor hypoglycemia are shown in Fig. 6: the mean IGF I level $(56 \pm 39 \mathrm{ng} / \mathrm{ml})$ is significantly decreased $(P<0.01)$. In three of four patients who were operated successfully and who had normal blood glucose levels after operation IR-IGF I rose within the

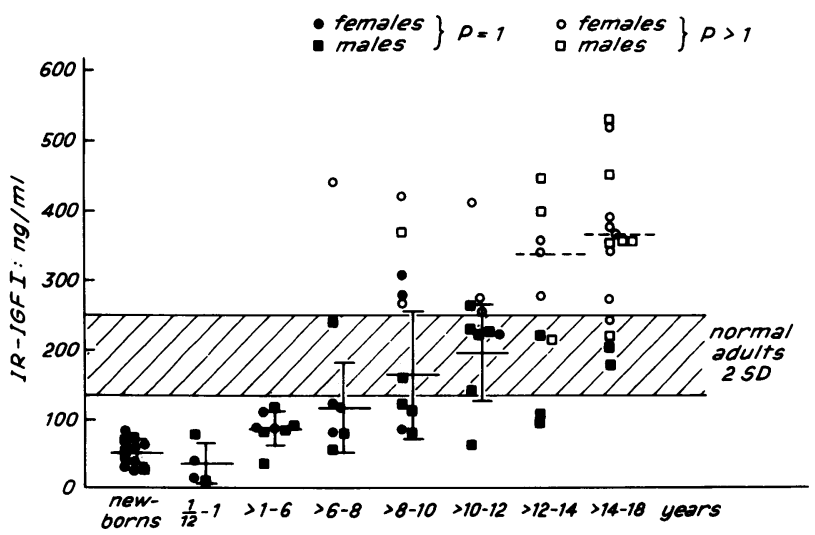

FIGURE 4 Dependence of serum immunoreactive IGF I levels on age and puberty in normal children. Immunoreactive IGF I was determined in gel filtered sera as described in Methods. Bars represent mean levels $\pm S D$ for prepubertal children. Broken lines represent mean levels for children with pubertal stage $>1$ according to Tanner (14). The hatched area indicates the mean IGF I level \pm SD for normal adults. Closed symbols: pubertal stage $=1$; open symbols: pubertal stage $>1$. $\bigcirc$, females: $\square$, males. All values were corrected for crossreactivity of IGF II.

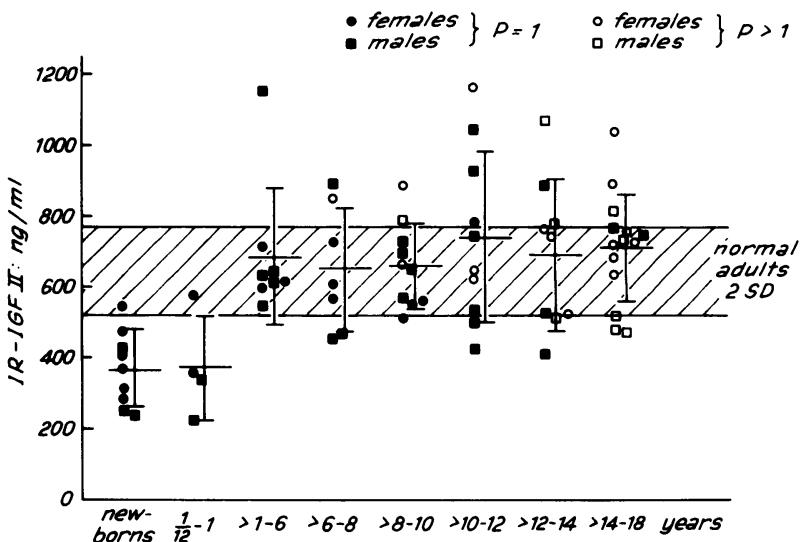

Figure 5 Dependence of serum immunoreactive IGF II levels on age and puberty in normal children. Immunoreactive IGF II was determined in gel filtered sera as described in Methods. Bars represent mean levels \pm SD. The hatched area gives the mean IGF II level \pm SD for normal adults. Closed symbols: pubertal state $(P)=1$ : open symbols: pubertal stage $>1$ : $\bigcirc$, females: $\square$, males. All values were corrected for cross-reactivity of IGF I.

normal range. IR-IGF II varied from 340 to $1,000 \mathrm{ng} /$ $\mathrm{ml}$. Its mean level $(556 \pm 195 \mathrm{ng} / \mathrm{ml})$ was statistically not significantly different from normal and remained unchanged after operation.

\section{DISCUSSION}

One of the problems encountered in the determination of IR-IGF in serum is caused by the tight association of IGF I and II with specific carrier protein(s) (16).
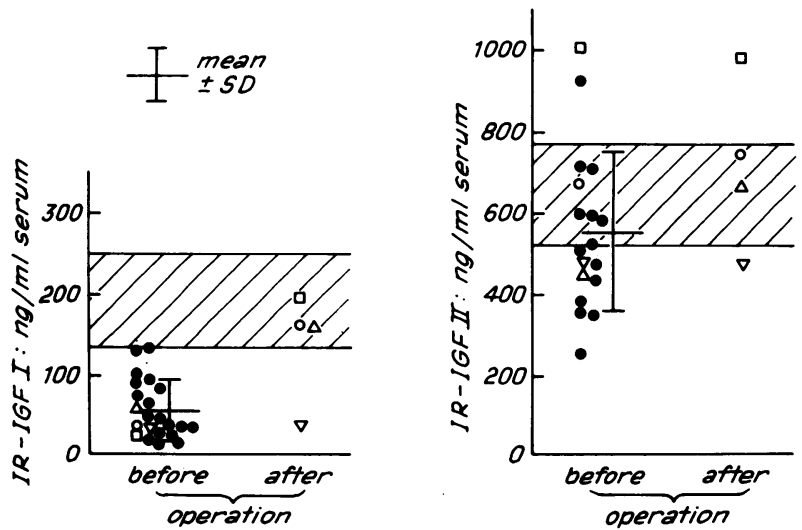

FIGURE 6 Immunoreactive serum IGF I and II levels in patients with extrapancreatic tumor hypoglycemia before and after successful removal of the tumor. IGF determinations were carried out in gel filtered sera as described in Methods. Bars represent mean levels \pm SD. The hatched area gives the mean $\pm S D$ of IGF I and II levels found in normal adult subjects. Open symbols represent patients before and after successful removal of the tumor. All values were corrected for crossreactivity of IGF I or II. 
The apparent affinities of IGF I and II toward the carrier protein(s) ( $\sim 1.6$ and $\sim 1.2 \mathrm{nM}$, respectively) (4) lie in an order of magnitude similar to the concentrations that cause half-maximal displacement in the RIA competition curves of Fig. $1(\sim 0.23$ and $\sim 0.37$ $\mathrm{nM})$. Since the carrier protein(s) in native serum is only partially saturated with IGF (17) the RIA in whole serum constitutes a complex multicomponent system. In this system the tracer may not only compete with the unlabeled native IGF-carrier complex for binding to the antibodies (Results), but may also bind to nonsaturated carrier protein(s). The resulting labeled IGFcarrier complex may then also compete with the free tracer and with the unlabeled carrier complex for the antibodies. One might expect that the unsaturated carrier protein, the amount of which is unknown and which may vary in different physiological and pathophysiological states, would influence the results of the RIA. Therefore, we do not carry out the IGF-RIA in whole serum. Even incubation under disequilibrium conditions does not help to solve the problem (Fig. 2). The values obtained for IGF I in whole serum are two- to threefold lower (depending on the serum dilution) than those obtained after dissociation and separation of IGF from the carrier protein(s) (Table I). The same observation has been made by Daughaday et al. (15). These authors extracted their serum samples with acid-ethanol, which dissociates the IGF-carrier complex and apparently removes the carrier protein. After acid-ethanol extraction they found IGF I values, determined by radioreceptor assay, and somatomedin $\mathrm{C}$ (SM-C) values measured by RIA, to lie 2.7- and 3fold higher than in the unextracted whole normal serum (15). They concluded from these results that the failure of quantitative recovery in whole serum may be due to "modification by steric and other factors of access of the somatomedin serum binding protein complex to membrane and immunobinding sites." Our IGF I RIA results in whole and gel filtered sera (Table I) would also be interpretable along this line.

The IGF-RIA introduced by Reber and Liske (18) was carried out in whole serum under equilibrium conditions. Therefore, the results are difficult to interpret. Furlanetto et al. (19) originally measured SM-C in whole serum under disequilibrium conditions. They now report that this procedure may underestimate SM-C (20). A similar finding was reported by Bala et al. (21) for a RIA measuring a SM-C-like polypeptide. Bala et al. (21) and Clemmons et al. (20) now acidify their serum samples ( $\mathrm{pH}$ 2.3-2.7), lyophilize them and reconstitute them before they carry out the RIA. However, the carrier protein is not removed by this procedure. A considerable amount of specific ${ }^{125}$ I-IGF binding is still demonstrable after this kind of pretreatment, although a 50-70\% loss of the binding activity occurs in the acid-lyophilized carrier protein frac- tion (as compared with that dialyzed against neutral buffer; unpublished observation). As shown in Table II this remaining amount of carrier protein may be responsible for the discrepancies between the RIA results obtained for different groups of patients in acid-chromatographed $50-80 \%$ bed vol fractions and those determined in the combined $0-80 \%$ serum fractions or in acid-treated whole sera. This reasoning is also borne out by comparing the latter RIA results with those obtained by the acid-ethanol extraction procedure of Daughaday et al. (15) by which the carrier protein is removed. Although the values measured after acidic gel filtration are 20-30\% lower than in acidethanol extracted sera the ratios between the results obtained after the two pretreatment procedures are relatively constant and independent of the group of patients or their IGF levels. This is in contrast to the results received in the presence of carrier protein (Table II).

The finding that after gel filtration immunoreactive serum IGF levels are lower than after acid-ethanol extraction of sera would be consistent with losses of IGF during the former procedure. This is indicated by the results of the recovery of exogenous IGF added to serum or albumin-buffer (Methods). The total recovery by the gel filtration method is $\sim 74 \%$, whereas Daughaday et al. (15) report a recovery of $100 \%$. $~ 10 \%$ of the IGF is "lost" in the $0-50 \%$ bed vol fraction on gel filtration, and $63-66 \%$ are recovered in the $50-80 \%$ pool. Based on the assumption that the recovery of exogenous is identical to that of endogenous IGF, all serum levels reported in this study would have to be multiplied by a factor of 1.5 .

Hall et al. (22) perform their SM-A RIA in whole serum using Sepharose-bound antibodies against SM-A and a 6-d incubation under disequilibrium conditions. Since in their RIA IGF I is $\sim 10$ times more potent than SM-A itself their SM-A levels in normal subjects $(\sim 1,000 \mathrm{ng} / \mathrm{ml})$ would correspond to $\sim 100 \mathrm{ng} / \mathrm{ml}$ of IGF I. This is close to the level of IGF I that we find in normal whole serum at a 1:10 dilution (Fig. 2).

The methodology presently used for the determination of IR-IGF I differs from the previous one (6) in the following respects: ( $a$ ) a new IGF I antiserum is used: (b) the smaller size of the columns and the simplified gel filtration procedure now allow to process small amounts of serum $(100 \mu \mathrm{l})$ and a reasonable number of serum samples (at least 20/day); (c) samples are now preincubated with the antiserum for $24 \mathrm{~h}$ before the tracer is added and incubation is continued for another $24 \mathrm{~h}$; under these conditions the sensitivity of the assay is increased; $(d)$ separation of the IGFantibody complex is performed by the double antibody technique instead of the charcoal separation.

Despite these modifications the results obtained in this study for the mean IGF I levels in normal, acro- 
megalic, and hypopituitary subjects are close to those reported earlier. The results confirm our previous data on the GH-dependence of IR-IGF I levels as well as the data of others on the GH-dependence of IR-SM-C $(19,23)$, IR-SM-A (22) and of a SM-C-like polypeptide (20). In addition, the investigation in patients with isolated GH deficiency demonstrates that the lack of GH alone, irrespective of an otherwise normal hormonal status, is responsible for the drastic decrease of IRIGF I in serum.

One of the results that differs from the earlier report (6) is the crossreactivity of SM-A in the IGF I RIA. It is $10 \%$ with the new antiserum, but was identical to IGF I with the antiserum used before (kindly supplied by Dr. Reber, Hoffmann-La Roche, Basel, Switzerland). The finding with the new antiserum agrees with that of Hall et al. (22), who reported that SM-A was $10 \%$ as potent as IGF I in their SM-A RIA (22). Thus, our new IGF I antiserum discriminates better between IGF I and SM-A.

The dependence of IGF I on age and its increase during puberty has also been reported by Hall et al. (24) for SM-A and by Bala et al. for a basic somatomedin (25), which is similar to SM-C/IGF I. In children below the age of $10 \mathrm{yr}$ it may be difficult to diagnose growth hormone deficiency on the basis of IR-IGF I: serum levels may lie within or close to the hypopituitary range. Measurement of IGF II in these situations, however, allows to distinguish between the normal and GH deficient state, since IGF II is significantly decreased in GH-deficient children (Zapf, J., unpublished observations).

The discrepancy between the high growth rate of newborns and their low IGF I and II levels is at first sight striking and appears to be at variance with the concept that somatomedins are GH-dependent stimulators of skeletal growth. However, any such conclusion would be invalid and meaningless as long as the mechanism of action of SM in vivo, the physiological role of the carrier protein and the sensitivity towards SM of tissues at various stages of development have not been disclosed. By the same token, it would be premature to conclude that the pubertal growth spurt is causally related to elevated IGF I levels.

The results of the IGF II RIA provide new information on the regulation of this factor: IR-IGF II is not increased in acromegalic patients. A similar finding was reported by Daughaday et al. (26) who used an IGF IIspecific rat placental membrane RRA and by Hintz and Liu (27), who developed a specific RIA for IGF II using an antibody against synthetic IGF II C-peptide. Our mean IR-IGF II levels in both normal and acromegalics are indistinguishable, i.e. 647 and 641 as compared with 867 and $869 \mathrm{ng} / \mathrm{ml}$ in Daughaday's study (26) and 710 and $541 \mathrm{ng} / \mathrm{ml}$, respectively in the study of Hintz and Liu (27). Thus, over-secretion of
GH does not cause an elevation of IR-IGF II. This is in striking contrast to the behavior of IGF I. Nevertheless, IGF II, like IGF I, is GH-dependent, since (a) GH deficiency is accompanied by significantly decreased IGF II levels $(252 \pm 99 \mathrm{ng} / \mathrm{ml}$ serum); this decrease is less pronounced in the IGF II RRA of Daughaday et al. (26) who found $620 \mathrm{ng} / \mathrm{ml}$, whereas the mean IGF II level reported by Hintz and Liu (27) for 10 hypopituitary patients was $170 \mathrm{ng} / \mathrm{ml}$. (b) GH treatment of hypopituitary dwarfs brings IGF II back into the normal range (Merimee, Zapf, and Froesch, unpublished observations). Thus, IGF II can now also be classified as a somatomedin as originally defined by Daughaday et al. (7). However, IGF II production appears to be already maximally stimulated at normal GH levels. Therefore, in contrast to IGF I, its GH dependence becomes apparent only when GH levels fall below normal. Altogether, our results indicate that IGF I and II levels are regulated differently and independently of each other. Decreased levels of IGF I do not necessarily entail a decrease in the IGF II level: whereas the mean IGF I level is significantly decreased in patients with extrapancreatic tumor hypoglycemia (ref. 6, Fig. 6), IGF II has been found to lie within the normal range (Fig. 6). The mode of regulation of IGF II is not yet known.

Hypoglycemia in patients with extrapancreatic tumors has been attributed to an elevation of IGF $(28,29)$. In such patients we have found earlier that total IGF levels (as determined biologically and by the protein binding assay) are either normal or slightly decreased (6). IR-IGF I levels in this earlier study were found to be significantly decreased in 5 of 10 patients (6). These findings together with our present results obtained for IR-IGF I and II in these patients speak against a causal relationship between IGF and this type of hypoglycemia. It is also unlikely that the increased ratio of IGF and IGF carrier protein (6) is responsible for the sustained hypoglycemia in these patients, since this ratio is decreased in acromegalics as well (6). Most acromegalics display some degree of glucose intolerance and hyperglycemia rather than hypoglycemia.

The discrepancy between our results and those of Megyesi et al. and Hyodo et al. $(28,29)$ is most likely due to methodological differences in the determination of IGF. Megyesi et al. measured IGF by a rat liver membrane radioreceptor assay. In some of the studies of these authors the partially purified IGF tracer (which contained both IGF I and II) was replaced by labeled MSA. Lately, Rechler et al. (30) have shown that IGF II and MSA behave similarly with respect to binding to rat liver membranes, whereas IGF I binds only poorly in this system and displaces ${ }^{125}$ I-IGF II with a potency of only $\sim 2 \%$ of that of IGF II. Therefore, Megyesi et al. (28) measured IGF II or a 
related factor rather than IGF I in their radioreceptor assay. This would also explain that they found normal IGF levels in acromegalic patients (31). IR-IGF II levels in acromegaly are in fact the same as in normal subjects (Fig. 3).

The increase in receptor-reactive material found by Megyesi et al. and by Hyodo et al. $(28,29)$ is unlikely to be attributable to an increase in IR-IGF II, which we do not find elevated in our tumor patients. Surprisingly, Daughaday et al. (26) recently reported that IGF II levels were elevated in five of six patients with nonislet cell tumors in the rat placental membrane RRA. All these findings would support the hypothesis that sera of patients with extrapancreatic tumor hypoglycemia may contain substances that crossreact with IGF II at the IGF II receptor of rat liver and rat placental membranes. Apparently, these substances do not crossreact at the insulin receptor of adipose tissue, since biologically active IGF in these sera, as tested in the fat pad or fat cell assay, is not elevated (6).

Further studies on the function of this unique IGF II receptor of liver and placental membranes are required before one can speculate about the role of such IGF II-like substances in the pathogenesis of tumor hypoglycemia.

\section{ACKNOWLEDGMENTS}

We thank Dr. R. E. Humbel, Zürich, for the generous supply of IGF I and II, Dr. T. Merimee, Gainesville, Fla., for providing sera from patients with isolated growth hormone deficiency, and Dr. A. Prader, Zürich, and Dr. Z. Laron, Petah Tiqva, Israel, for providing sera from normal children. The technical assistance of M. Waldvogel, B. Ruf, and J. Grunwald, and the secretarial work of R. Maurer are highly appreciated.

This work was supported by grant 3.380-0.78 of the Swiss National Science Foundation.

\section{REFERENCES}

1. Rinderknecht, E., and R. E. Humbel. 1978. The amino acid sequence of human insulin-like growth factor I and its structural homology with proinsulin. J. Biol. Chem. 253: 2769-2776.

2. Rinderknecht, E., and R. E. Humbel. 1978. Primary structure of human insulin-like growth factor II. FEBS (Fed. Eur. Biochem. Soc.) Lett. 89: 283-286.

3. Froesch, E. R., H. Bürgi, E. B. Ramseier, P. Bally, and A. Labhart. 1963. Antibody-suppressible and nonsuppressible insulin-like activities in human serum and their physiologic significance. An insulin assay with adipose tissue of increased precision and specificity. J. Clin. Invest. 42: 1816-1834.

4. Zapf, J., E. Schoenle, and E. R. Froesch. 1978. Insulinlike growth factors I and II: some biological actions and receptor binding characteristics of two purified constituents of nonsuppressible insulin-like activity of human serum. Eur. J. Biochem. 87: 285-296.

5. Froesch, E. R., J. Zapf, T. K. Audhya, E. Ben-Porath, B. J. Segen, and K. D. Gibson, 1976. Nonsuppressible insulinlike activity and thyroid hormones. Major pituitary- dependent sulfation factors for chick embryo cartilage. Proc. Natl. Acad. Sci. U. S. A. 73: 2904-2908.

6. Zapf, J., B. Morell, H. Walter, Z. Laron, and E. R. Froesch. 1980. Serum levels of insulin-like growth factor (IGF) and its carrier protein in various metabolic disorders. Acta Endocrinol. 95: 505-517.

7. Daughaday, W. H., K. Hall, M. S. Raben, W. D. Salmon, Jr., L. J. van den Brande, and J. J. van Wyk. 1972. Somatomedin: proposed designation for sulfation factor. Nature Lond.). 235: 107.

8. Van Wyk, J. J., M. E. Svoboda, and L. E. Underwood. 1980. Evidence from radioligand assays that somatomedin C and insulin-like growth factor I are similar to each other and different from other somatomedins. J. Clin. Endocrinol. Metab. 50: 206-208.

9. Svoboda, M. E., J. J. van Wyk, D. G. Klapper, R. E. Fellows, F. E. Grissom, and R. J. Schlueter. 1980. Purification of somatomedin C from human plasma. Chemical and biological properties, partial sequence analysis and relationship to other somatomedins. Biochemistry. 19: 790-797.

10. Hintz, R. L., F. Liu, L. B. Marshall, and D. Chang. 1980. Interaction of somatomedin $\mathrm{C}$ with an antibody directed against the synthetic $\mathrm{C}$-peptide region of insulin-like growth factor I. J. Clin. Endocrinol. Metab. 50: 405-407.

11. Hintz, R. L., F. Liu, and E. Rinderknecht. 1980. Somatomedin $\mathrm{C}$ shares the carboxy-terminal antigenic determinants with insulin-like growth factor I. J. Clin. Endocrinol. Metab. 51: 672-673.

12. Merimee, T. J., and D. Rabinowitz. 1974. Isolated human growth hormone deficiency and related disorders. Monograph. Stratton International Medical Book Corporation, New York.

13. Rimoin, D. L., T. J. Merimee, D. Rabinowitz, and V. A. McKusick. 1968. Genetic aspects of clinical endocrinology. Rec. Progr. Horm. Res. 24: 365-437.

14. Tanner, J. M. 1962. Wachstum und Reifung des Menschen. Thieme Verlag, Stuttgart.

15. Daughaday, W. H., I. K. Mariz, and S. L. Blethen. 1980. Inhibition of access of bound somatomedin to membrane receptor and immunobinding sites. A comparison of radioreceptor and radioimmunoassay of somatomedin in native and acid-ethanol-extracted serum. J. Clin. Endocrinol. Metab. 51: 781-788.

16. Zapf, J., M. Waldvogel, and E. R. Froesch. 1975. Binding of nonsuppressible insulin-like activity to human serum. Evidence for a carrier protein. Arch. Biochem. Biophys. 168: 638-645.

17. Zapf, J., G. Jagars, I. Sand, and E. R. Froesch. 1978. Evidence for the existence in human serum of large molecular weight nonsuppressible insulin-like activity (NSILA) different from the small molecular weight form. FEBS (Fed. Eur. Biochem. Soc.) Lett. 90: 135-140.

18. Reber, K., and R. Liske. 1976. Radioimmunoassay for nonsuppressible insulin-like activity. Horm. Res. 7: 201-213.

19. Furlanetto, R. W., L. E. Underwood, J. J. van Wyk, and A. J. D'Ercole. 1977. Estimation of somatomedin-C levels in normals and patients with pituitary disease by radioimmunoassay. J. Clin. Invest. 60: 648-657.

20. Clemmons, D. R., L. E. Underwood, and J. J. van Wyk. 1981. Hormonal control of immunoreactive somatomedin production by cultured human fibroblasts. J. Clin. Invest. 67: 10-19.

21. Bala, R. M., and B. Bhaumick. 1979. Radioimmunoassay of a basic somatomedin. Comparison of various assay techniques and somatomedin levels in various sera. J. Clin. Endocrinol. Metab. 49: 770-777. 
22. Hall, K., J. Brandt, G. Engberg, and L. Fryklund. 1979. Immunoreactive somatomedin A in human serum.J. Clin. Endocrinol. Metab. 48: 271-278.

23. Clemmons, D. R., J. J. van Wyk, E. C. Ridgway, B. Kliman, R. N. Kjellberg, and L. E. Underwood. 1979. Evaluation of acromegaly by radioimmunoassay of somatomedin C. N. Engl. J. Med. 301: 1138-1142.

24. Hall, K., G. Engberg, M. Ritzén, H. Svan, L. Fryklund and K. Takano. 1980. Somatomedin A levels in serum from healthy children and from children with growth hormone deficiency or delayed puberty. Acta Endocrinol. 94: 155-165.

25. Bala, R. M., J. Lopatka, A. Leung, E. McCoy, and R. G. McArthur. 1981. Serum immunoreactive somatomedin levels in normal adults, pregnant women at term, children at various ages, and children with constitutionally delayed growth. J. Clin. Endocrinol. Metab. 52: 508-512.

26. Daughaday, W. H., B. Trivedi, and I. K. Mariz. 1980. Elevated insulin-like growth factor II (IGF II) in nonislet tumor induced hypoglycemia detected by a new specific radioreceptor assay. Diabetes. 29 Suppl. 2: 5A. (Abstr.) 19.
27. Hintz, R. L., and F. Liu. 1981. Insulin-like growth factor II radioimmunoassay based on an antiserum against the synthetic C-peptide segment. Clin. Res. 29: 408A (Abstr.)

28. Megyesi, K., C. R. Kahn, J. Roth, and Ph. Gorden. 1974. Hypoglycemia associated with extrapancreatic tumours: demonstration of elevated plasma NSILA-S by a new radioreceptor assay. J. Clin. Endocrinol. Metab. 38: 931-934.

29. Hyodo, T., K. Megyesi, C. R. Kahn, J. P. McLean, and H. G. Friesen. 1977. Adrenocortical carcinoma and hypoglycemia. Evidence for production of nonsuppressible insulin-like activity by the tumour. J. Clin. Endocrinol. Metab. 44: 1175-1184.

30. Rechler, M. M., J. Zapf, S. P. Nissley, E. R. Froesch, A. C. Moses, J. M. Podskalny, E. E. Schilling, and R. E. Humbel. 1980. Interactions of insulin-like growth factors I and II and multiplication stimulating activity with receptors and serum carrier proteins. Endocrinol. 107: 1451-1459.

31. Megyesi, K., Ph. Gorden and C. R. Kahn. 1977. Lack of a simple relationship between endogenous growth hormone and NSILA-S related peptide.J. Clin. Endocrinol. Metab. 45: $330-338$. 